\title{
Ecological Analysis of Plant Cover of the Permanent Grassland Ecosystem Located in the Vicinity of Novi Kneževac, Serbia
}

\author{
Aleksa Knežević • Branka Ljevnaić-Mašić • Dejana Džigurski • Branko Ćupina
}

\author{
received: 22 June 2011, accepted: 3 February 2012 \\ (c) 2012 IFVC \\ doi: $10.5937 /$ ratpov49-1203
}

\begin{abstract}
Summary: A total of 205 taxa and stands of 12 plant communities were found to comprise the plant cover of the permanent grassland on the solonetz and solonchakic solonetz soils located in the vicinity of the town of Novi Kneževac (Vojvodina Province, Serbia). The registered taxa included 177 plant species, six subspecies, eight varieties, 13 forms and one lusus. The ecological analysis of the flora involved 191 taxa. That group consisted of 177 species, six subspecies, three varieties and five forms. The three varieties, Aster tripolium L. var. pannonicus (Jacq.) Beck, Chenopodium rubrum L. subsp. botryoides Sm. var. crassifolium (Hornem) Kov. and Sonchus arvensis L. var. uliginosus (M.B.) Grec. were used for analysis because their higher taxonomic categories were not recorded in the studied flora. The five forms, Aster sedifolius L. f. subsquamosus Soó, Bromus commutatus Schrad. f. violaceus Podp., Mentha aquatica L. f. erromera Top., Poa bulbosa L. f. vivipara Koel. and Scleranthus annus L. f. minimus Schur., were used for the same reason. The ecological analysis encompassed stands of all 12 recorded communities, i.e. ass. Scirpo-Phragmitetum W. Koch 1926, ass. Bolboschoenetum maritimi continentale Soó (1927) 1957, ass. Acorelletum pannonici Soó (1939) 1947, ass. Puccinelletum limosae (Rapcs. 1927) Soó 1930, ass. Pholiuro-Plantaginetum tenuiflorae (Rapcs. 1927) Wendel. 1943, ass. Hordeetum histricis (Soó 1933) Wendel. 1943, ass. Camphorosmetum annuae (Rapcs. 1916) Soó 1933 corr. Soó 1938, ass. Agrostio-Alopecuretum pratensis Soó (1933) 1947, ass. Agrostio-Eleochariti-Alopecuretu geniculati (Magyar 1928) Soó (1939) 1947, ass. Artemisio-Festucetum pseudovinae (Magyar 1928) Soó 1945, ass. Achilleo-Festucetum pseudovinae (Magyar 1928) Soó 1945 and ass. Festuco-Andropogonetum ischaemi Vučk. 1985. The ecological analysis of the plant cover indicated that halophytes made $30.37 \%$ of the flora of the permanent grassland near the town of Novi Kneževac, and that the stands of the recorded plant communities grew on sites that differed widely in the salt content in the rhizosphere soil layer. On average, these sites were moderately dry (F - 2.72) and moderately basic ( R - 3.26), with moderate contents of nitrogen and nitrogen-containing substances $(\mathrm{N}-3.07)$, a medium humus content $(\mathrm{H}-2.94)$ and a moderately favourable aeration (D - 3.99). The plant cover of these sites, typical for meadows, was dominated by thermophilous plants adapted to full light $(\mathrm{T}-4.05)$ but also to some shading $(\mathrm{L}-3.84)$ as well as to the continental climate of the studied location ( $\mathrm{K}-3.27)$.
\end{abstract}

Key words: ecological indices, Novi Kneževac, grasslands, plant cover, solonetz, solonchakic solonetz, taxa

\section{Introduction}

The town of Novi Kneževac lies along the Tisza River, in northern Banat (Vojvodina Province, Serbia). According to the data from the nearest meteorological station in Kikinda, the average annual precipitation in this region is $555 \mathrm{~mm}$ and the average annual temperature is $11.1^{\circ} \mathrm{C}$. A climate diagram after Walter shows that the beginning of the vegetation period (April) is marked by a substantial increase in precipitation

A. Knežević • B. Ljevnaić-Mašić* • D. Džigurski • B. Ćupina University of Novi Sad, Faculty of Agriculture, Trg Dositeja Obradovića 8, 21000 Novi Sad, Serbia

e-mail: brana@polj.uns.ac.rs and a high but gradual increase in temperature. After maximum levels reached in June, the rainfall drops considerably in subsequent months. In contrast to precipitation, the temperature, that gradually increases at the beginning of the vegetation period, remains steady and high in the middle of the vegetation period, and begins to go down perceptibly not earlier than October. Because of the above precipitation and temperature patterns, the studied region passes through a semi-arid period from mid-July to late

Acknowledgement: This study is part of the project TR31016 titled „Improvement of field forage crops agronomy and grassland management" financed by the Ministry for Education and Science of the Republic of Serbia. 
September, which negatively affects the vegetation cover (Ljevnaić-Mašić 2010). East of Novi Kneževac, there are large areas of the solonetz and solonchakic solonetz soils (Benka \& Salvai 2005). These areas have not been turned to agricultural use due to low contents of organic matter. They are overgrown with their native vegetation and are used mostly for domestic animals grazing, less frequently for mowing.

The objective of this study was to establish the ecology of the permanent grassland on the solonetz and solonchakic solonetz soils located in the vicinity of the town of Novi Kneževac on the basis on average values of the ecological indices of the analyzed plant taxa and the analysis of the sites of the registered plant communities.

\section{Material and Methods}

The study of the ecology of the permanent grassland on the the solonetz and solonchakic solonetz soils, located in the vicinity of Novi Kneževac, was based on manuscript by Knežević et al. (2011). Ecological indices used in the analyses of plant response to salinity - $S$, humidity -F, soil chemical reaction - R, contents of nitrogen and nitrogen-containing compounds - N, content of humus, i.e., organic matter - H, dispersion (aeration) - D, temperature - $\mathrm{T}$, light $\mathrm{L}$ and continentality - K were by Landolt (1977). The taxa that had not been characterized by Landolt were characterized by Knežević (1994). The analysis included 191 taxa, i.e., 177 species, six subspecies, three varieties and five forms. The three varieties (Aster tripolium L. var.pannonicus (Jacq.) Beck, Chenopodium rubrum L. subsp. botryoides $\mathrm{Sm}$. var. crassifolium (Hornem) Kov. and Sonchus arvensis L. var. uliginosus (M.B.) Grec.) and the five forms (Aster sedifolius L. f. subsquamosus Soó, Bromus commutatus Schrad. f. violaceus Podp., Mentha aquatica L. f. erromera Top., Poa bulbosa L. f. vivipara Koel. and Scleranthus annus L. f. minimus Schur.) were analyzed because their higher taxonomic categories were not registered in the studied flora. The following parameters were calculated for the above plant material: the number and percentage of taxa adapted to saline soil $\left(\boldsymbol{S}_{+}\right)$, the number and percentage of taxa not adapted to saline soil $(\mathbf{S})$, numerical values of the analyzed ecological indices, number of taxa having the same numerical values of individual ecological indices, percentage of taxa having the same numerical values of individual ecological indices and the mean values of individual ecological indices (Tab. 1).

\section{Results and Discussion}

The flora of the permanent grassland on the solonetz and solonchakic solonetz soils, located in the surroundings of the town of Novi Kneževac (Vojvodina Province, Serbia), was found to comprise 205 taxa: 177 species, six subspecies, eight varieties, 13 forms and one lusus (Knežević et al. 2011). The ecological analysis of the flora involved 191 taxa. That group consisted of 177 species, six subspecies, three varieties i.e. Aster tripolium L. var. pannonicus (Jacq.) Beck, Chenopodium rubrum L. subsp. botryoides Sm. var. crassifolium (Hornem) Kov. and Sonchus arvensis L.var.uliginosus (M.B.) Grec., because their higher taxonomic categories were not registered in the studied flora, and five forms i.e. Aster sedifolius L. f. subsquamosus Soó, Bromus commutatus Schrad. f. violaceus Podp., Mentha aquatica L. f. erromera Top., Poa bulbosa L. f. vivipara Koel. and Scleranthus annus L. f. minimus Schur. because their higher taxonomic categories were not registered in the studied flora. The vegetation of the permanent grassland on the solonetz and solonchakic solonetz soils located in the vicinity of Novi Kneževac was found to be comprised of 12 plant associations: ass. Scirpo-Phragmitetum W. Koch 1926, ass. Bolboschoenetum maritimi continentale Soó (1927) 1957, ass. Acorelletum pannonici Soó (1939) 1947, ass. Puccinelletum limosae (Rapcs. 1927) Soó 1930, ass. PholiuroPlantaginetum tenuiflorae (Rapcs. 1927) Wendel. 1943, ass. Hordeetum histricis (Soó 1933) Wendel. 1943, ass. Camphorosmetum annuae (Rapcs. 1916) Soó 1933 corr. Soó 1938, ass. Agrostio-Alopecuretum pratensis Soó (1933) 1947, ass. Agrostio-Eleochariti-Alopecuretu geniculati (Magyar 1928) Soó (1939)1947, ass. ArtemisioFestucetum pseudovinae (Magyar 1928) Soó 1945 , ass. Achilleo-Festucetum pseudovinae (Magyar 1928) Soó 1945 and ass. Festuco-Andropogonetum ischaemi Vučk. 1985 (Knežević et al. 2011).

\section{Plant reaction to salinity - $S$}

Out of the 191 analyzed taxa that comprised the flora of the grassland on the solonetz and solonchakic solonetz soils in the vicinity of Novi Kneževac, 58 (30.37\%) of them were labelled with the ecological index $S_{+}$. Their presence indicated the halophytic character of the analyzed flora, i.e. high salt concentrations were observed in spots scattered across the grassland located in the vicinity of the town of Novi Kneževac. The high salt concentrations were found in the rhizosphere soil. The degree of their salinity is lower than sites located in the vicinity of the 
towns Melenci - Rusanda (Knežević et al. 2003), Melenci - Ostrovo (Knežević et al. 2005b), Novi Bečej - Slano Kopovo (Knežević et al. 2005a) and Kumane (Knežević et al. 2009a), and higher than at the habitat located in the vicinity of the town Elemir - Okanj (Knežević et al. 2009b). The taxa labelled with the ecological index $S$ in the grassland located in the vicinity of the town of Novi Kneževac are represented by 133 taxa or $69.63 \%$ of the analysed taxa. Their presence indicated that large portions of the studied grassland were in the process of salt leaching, i.e. these parts of the grassland contained high salt concentrations only in deep soil layers. The above statement was based on the analysis of the position of the stands of the 12 identified plant communities. Stands of swamp and marsh vegetation of the class Phragmitetea Tx. et Prsg. 1942 , located on the banks of non-saline stagnant waters / Ass. Scirpo-Phragmitetum W. Koch 1926/ and saline stagnant waters/Ass. Bolboschoenetum maritimi continentale Soó (1927)1957/, grew in fragments and they covered small areas. Stands of annual, mostly succulent halophytes of the class Thero-Salicornietea Tx. 1955, Tx. et Ober. 1958 /Ass. Acorelletum pannonici Soó (1939) $1947 /$ tended to develop in the later part of the semiarid period, covering small areas of the dry peripheral parts of a former meander of the Tisza River which had been converted into a fishpond. The latter stands, which belong to the subassociation Acorelletum pannonici Soó (1939)1947 pycretosum flavescenti Knež. 1983, included a number of species that belong to the classes Phragmitetea Tx.et Prsg. 1942, IsoëtoNanojuncetea Br.-Bl. et Tx. 1943 and ChenopodioScleranthea Hadač 1967 (Knežević 1983). Stands of the meadow-steppe vegetation of continental salinas, of the class Festuco-Puccinellietea Soó 1968, the order Festuco-Puccinellietalia Soó 1968, the alliance Puccinellion limosae (Klika 1937) Wendel. 1943, which form meadows at more saline sites / Ass. Puccinelletum limosae (Rapcs. 1927) Soó 1930, Ass. Pholiuro-Plantaginetum tenuiflorae (Rapcs. 1927) Wendel. 1943, Ass. Hordeetum histricis (Soó 1933) Wendel. 1943 and Ass. Camphorosmetum annuae (Rapcs. 1916) Soó 1933 corr. Soó 1938/, and stands of the alliance Halo-Agrostion albae pannonicum Knežević 1990, which form meadows at less saline sites / Ass. Agrostio-Alopecuretum pratensis Soó (1933) 1947 and Ass. Agrostio-Eleochariti-Alopecuretu geniculati (Magyar1928) Soó (1939)1947/, occupy modest surfaces. Stands of the meadowsteppe vegetation of continental salinas, of the class Festuco-Puccinellietea Soó 1968, the order
Artemisio-Festucetalia pseudovinae Soó 1968, the alliance Festucion pseudovinae Soó 1933, which form a meadow-steppe vegetation at slightly saline sites /Ass. Artemisio-Festucetum pseudovinae (Magyar 1928) Soó 1945 and Achilleo-Festucetum pseudovinae (Magyar 1928) Soó 1945/, and stands of the meadow-steppe vegetation of the class Festuco-Brometea Br.-Bl. et Tx.1943, which form a meadow-steppe vegetation at sites in which salts are accumulated in high concentrations only in deep soil layers /Ass. Festuco-Andropogonetum ischaemi Vučk. 1985/, were the dominant plant cover of the analyzed grassland.

\section{Plant reaction to the humidity of the site - F}

The analysis of ecological indices for moisture $(F)$ indicated that the plant cover of the grassland on the solonetz and solonchakic solonetz soils in the vicinity of the town of Novi Kneževac consisted of plants adapted to all levels of humidity of the site. Plants of dry habitats, labelled with the ecological index $\mathrm{F}_{2}$, were most abundant (61 taxa - 31.94\%). Indicators of extremely dry sites, i.e. xerophytic plants labelled with the ecological index $F_{1}$, comprised a significant portion of the registered plants ( 28 taxa $-14.66 \%)$. Counted together, the plants labelled with the ecological indices $\mathrm{F}_{2}$ and $\mathrm{F}_{1}$ were represented by 89 taxa, i.e. the plants of arid and extremely arid sites comprised $46.60 \%$ of the recorded flora. Indicators of medium humid sites, i.e., mesophytic plants labelled with the ecological index $\mathrm{F}_{3}$, made less than one third of the registered plants (58 taxa-30.37\%). Indicators of highly humid sites, i.e. hygrophytic plants labelled with the ecological index $\mathrm{F}_{4}$, were much fewer (24 taxa - 12.56\%), similarly to the hydrophytic-hydrohelophytic plants, those labelled with the ecological index $\mathrm{F}_{5}$, which made the smallest group of the recorded plants (20 taxa - 10.47\%). Counted together, the plants labelled with the ecological indices $\mathrm{F}_{4}$ and $\mathrm{F}_{5}$ were represented by 44 taxa, i.e. the plants of humid and highly humid sites comprised $23.03 \%$ of the recorded flora. The percents presented above testify that, when we consider the humidity of the analyzed sites, the grassland on the solonetz and solonchakic solonetz soils in the vicinity of the town of Novi Kneževac consisted of different ecological niches. The development of plant indicators of extremely dry $\left(F_{1}\right)$ and dry $\left(F_{2}\right)$ sites in the highest parts of the grassland is a consequence of the physiological drought caused by a semi-arid period from midJuly to late September, which is adverse for the vegetation of the studied area. The growth of 
plant indicators of medium humid $\left(\mathrm{F}_{3}\right)$ sites was characteristic for the lower parts of the grassland and it was brought about by a low concentration of the soil solution reduced by spring rains. The growth of indicators of wet (F4) and extremely wet (F5) sites in natural depressions and the banks of canals and the fishpond constructed in a drained meander of the Tisza River was enabled by the high groundwater table, accumulation of atmospheric water and water added during periods of severe droughts. Therefore, the relationship between the recorded plants and the moisture in the studied grassland was governed by climatic, edaphic, microrelief and anthropogenic factors. The mean value of the ecological index for humidity calculated for the analyzed taxa was $\mathrm{F}$ - 2.72. It was an indication that, on average, the grassland on the solonetz and solonchakic solonetz soils in the vicinity of the town of Novi Kneževac was a moderately dry site.

Plant reaction to the chemical reaction of soil - $R$ The analyzed flora was dominated by neutrophile plants labelled with the ecological index $\mathrm{R}_{3}$ (118 taxa-61.78\%). There was also a significant number of indicators of neutral to basic soil chemical reaction bearing the ecological index $\mathrm{R}_{4}(62$ taxa $-32.46 \%)$. Indicators of acid soil chemical reaction bearing the ecological index $\mathrm{R}_{2}$ were much fewer (10 taxa-5.24\%). The number

Table 1. Ecological analysis of the flora of a permanent grassland located on solonetz and solonchakic solonetz soils in the vicinity of Novi Kneževac

Tabela 1. Ekološka analiza flore prirodnog pašnjaka, na solonjecu i solonjecu solončakastom, u okolini naselja Novi Kneževac

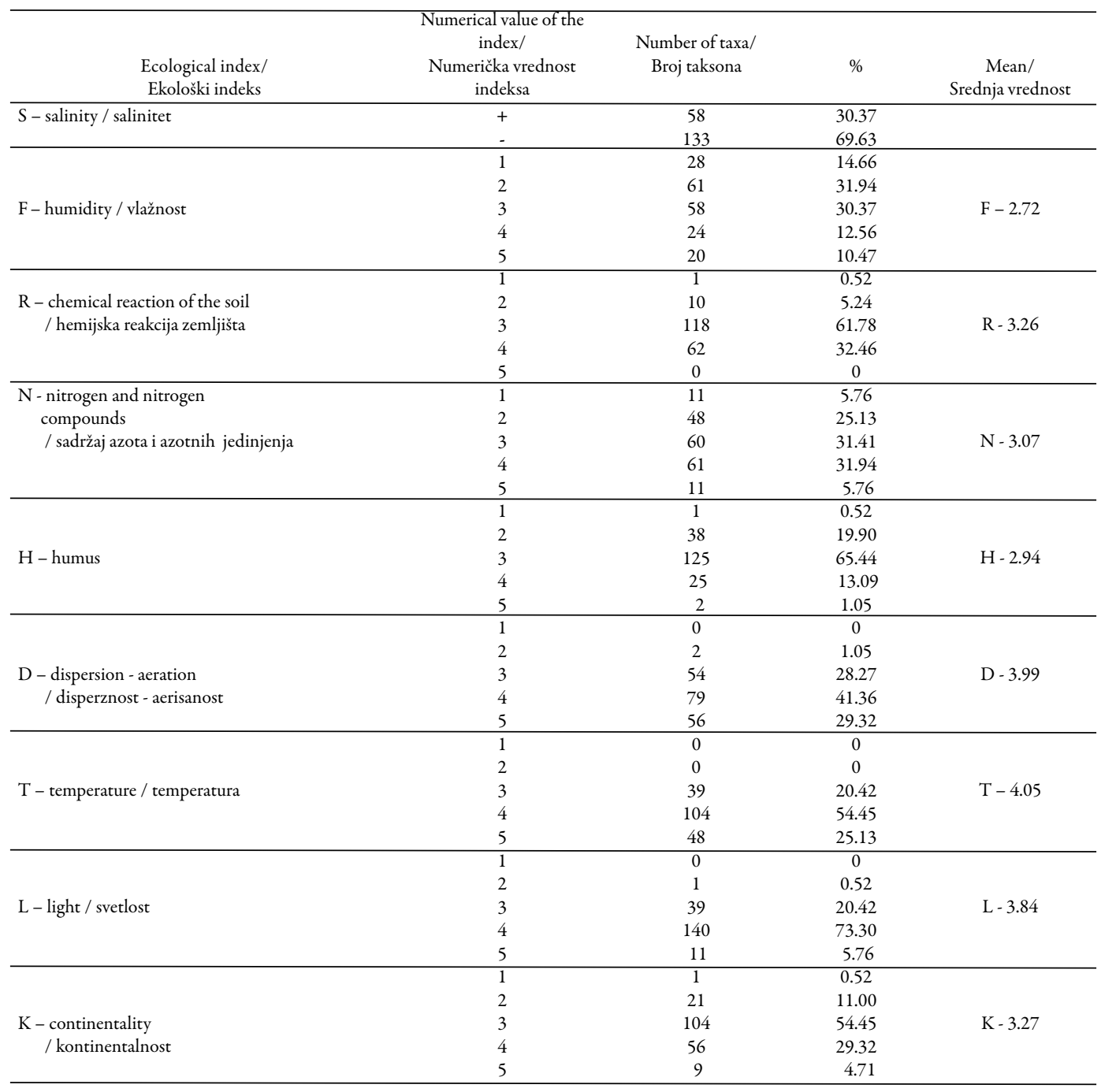


of indicators of strongly acid soils bearing the ecological index $R_{1}$ was negligible (one taxon $0.52 \%)$. Indicators of strongly basic soil bearing the ecological index $R_{5}$ were not represented in the analyzed flora. The mean value of the ecological index for soil chemical reaction calculated for the analyzed taxa was $\mathrm{R}-3.26$, which indicated that, on average, the plant cover of the grassland on the solonetz and solonchakic solonetz soils in the vicinity of the town of Novi Kneževac grew on a moderately basic soil.

Plant reaction to the contents of nitrogen and nitrogen-containing compounds in soil - $N$

The analysis of the flora included taxa adapted to all levels of nitrogen and nitrogen-containing compounds. The most numerous among them were labelled with the ecological index $\mathrm{N}_{4}$ (61 taxa $31.94 \%)$. Those were the taxa adapted to growing in sites that are provided with nitrogen and nitrogencontaining substances. Only slightly fewer were the taxa labelled with the ecological index $\mathrm{N}_{3}(60$ taxa-31.41\%). These taxa were indicators of sites with moderate contents of nitrogen and nitrogencontaining compounds. The following group were the taxa labelled with the ecological index $\mathrm{N}_{2}$ ( 48 taxa $-25.13 \%$ ). That group involved indicators of sites poor in nitrogen and nitrogen-containing substances. The taxa labelled with the ecological index $\mathrm{N}_{1}$, which grow in sites with low amounts of nitrogen and nitrogen-containing compounds, and the taxa labelled with the ecological index $\mathrm{N}_{5}$, which grow in sites with high amounts of nitrogen and nitrogen-containing compounds, formed two fairly small groups (11 taxa - 5.76\% in both cases). When counted together, the plants labelled with the ecological indices $\mathrm{N}_{1}$ and $\mathrm{N}_{2}(59$ taxa $30.89 \%$ ), i.e. the taxa that grew in oligotrophic parts of the analyzed ecosystem, formed a less numerous group than the plants labelled with the ecological indices $\mathrm{N}_{4}$ and $\mathrm{N}_{5}$ (72 taxa-37.70\%), i.e. the taxa that grew in eutrophic parts of the ecosystem. Based on the mean value of $\mathrm{N}-3.07$, we concluded that the grassland on the solonetz and solonchakic solonetz soils in the vicinity of the town of Novi Kneževac formed a mesotrophic, i.e. a medium-productive ecosystem, since the sites it comprised were provided with moderate contents of nitrogen and nitrogen-containing compounds.

\section{Plant reaction to the content of humus in soil $-H$}

The analysis of the ecological index for the content of humus showed that the taxa labelled with the ecological index $\mathrm{H}_{3}$ (125 taxa - 65.44\%) dominated the grassland on the solonetz and solonchakic solonetz soils in the vicinity of the town of Novi Kneževac. This indicates that most of the sites belonging to the analyzed grassland had medium humus content. Indicators of sites with a low organic matter content, labelled with the ecological index $\mathrm{H}_{2}$, were considerably less numerous (38 taxa - 19.90\%). Indicators of sites relatively rich in organic matter, labelled with the ecological index $\mathrm{H}_{4}$, were somewhat fewer than the previous group (25 taxa - 13.09\%). There were only a few indicators of sites rich in humus, labelled with the ecological index $\mathrm{H}_{5}$, and sites with no humus in the soil, labelled with the ecological index $\mathrm{H}_{1}$ (2 taxa or $1.05 \%$ and 1 taxon or $0.52 \%$, respectively). The mean value of the ecological index for the content of humus of $\mathrm{H}$ - 2.94 characterized the grassland on the solonetz and solonchakic solonetz soils in the vicinity of the town of Novi Kneževac as medium humic.

\section{Plant reaction to dispersion (aeration) of soil $-D$}

Most taxa composing the grassland on the solonetz and solonchakic solonetz soils in the vicinity of the town of Novi Kneževac were labelled with the ecological index $\mathrm{D}_{4}$ (79 taxa - 41.36\%). These taxa were adapted to a moderately wellaerated soil. They were followed by the taxa labelled with the ecological indices $\mathrm{D}_{5}(56$ taxa-29.32\%), i.e those adapted to a poorly aerated soil, and the taxa labelled with the ecological index $\mathrm{D}_{3}(54$ taxa - $28.27 \%)$, i.e. the taxa adapted to a well-aerated soil. Plants species adapted to soils composed of large particles, i.e. those labelled with the environmental index $\mathrm{D}_{2}$, were poorly represented (two taxa-1.05\%). Indicators of undeveloped soil, i.e. plant species labelled with the ecological index $\mathrm{D}_{1}$, were not found in the studied grassland. The mean value of $\mathrm{D}-3.99$ is an indication that the grassland on the solonetz and solonchakic solonetz soils in the vicinity of the town of Novi Kneževac are moderately well-aerated sites.

\section{Plant reaction to temperature - $T$}

The analysis of the ecological index for temperature showed that thermophilous plants, those labelled with the ecological index $\mathrm{T}_{4}$, dominated the flora of the studied grassland (104 taxa-54.45\%). Thermophilous preferences of the grassland flora were further indicated by a significant percentage of extremely thermophilous plants, those labelled with the ecological index $\mathrm{T}_{5}$ (48 taxa-25.13\%). In the stands growing on fairly moist soils, there were numerous mesothermic plants adapted to moderately warm sites (39 taxa $-20.42 \%$ ). These plants were labelled with the ecological index $\mathrm{T}_{3}$. Taxa adapted to growing in cold sites, labelled with the ecological index 
$\mathrm{T}_{2}$, and taxa of very cold sites, labelled with the ecological index T1, were not registered in the flora of the studied grassland. The mean value of $\mathrm{T}-4.05$ indicated a dominance of thermophilous plants in the plant cover of the studied grassland.

\section{Plant reaction to light $-L$}

The studied flora was dominated by taxa labelled with the ecological index $\mathrm{L}_{4}(140$ taxa $73.30 \%$ ), i.e. by plants adapted to conditions of full light, but tolerant to some shading. The taxa labelled with the ecological index $\mathrm{L}_{3}$ which are indicators of semi-shade, were much fewer (39 taxa-20.42\%). Their presence indicated that in some places these plants grew in dense stands. The number of plant species labelled with the ecological index $\mathrm{L}_{5}(11$ taxa $-5.76 \%)$, i.e. plants that do not tolerate shading, was small, but their presence was important because it suggested that degradation processes existed in the studied grassland ecosystem. The flora of the studied grassland included a single plant species tolerant to shading, labelled with the ecological index $\mathrm{L}_{2}$ (1 taxon - $\left.0.52 \%\right)$. The flora of the studied grassland included no plant species labelled with the ecological index $L_{1}$, i.e. plant indicators of full shadow. The mean value of $\mathrm{L}-3.84$ bore witness that the plant communities that formed the native plant cover of the grassland on the solonetz and solonchakic solonetz soils in the vicinity of the town of Novi Kneževac mostly grew in moderately dense stands. In other words, the studied flora was dominated by plant species adapted to the conditions of full light and limited shading. Still, plant species tolerant to semi-shade found favourable conditions for growth in the understorey of the studied plant stands.

\section{Plant reaction to continentality $-K$}

The analysis of the adaptation of the studied flora to the continental climate showed that most of the present plant species were adapted to the conditions of the moderate continental climate, i.e. they were labelled with the ecological index $\mathrm{K}_{3}$ (104 taxa $-54.45 \%)$. The larger number of plant species labelled with the ecological index $\mathrm{K}_{4}$ than those labelled with the index $\mathrm{K}_{2}$ (56 taxa $-29.32 \%$ and 21 taxa $-11.00 \%$, respectively) testified that the studied location was more affected by the continental climate from east and north than by the suboceanic climate from west and south. The low proportion of taxa labelled with the ecological index $\mathrm{K}_{5}$ (9 taxa - 4.71\%) resulted from occasional influences of the continental climate, while the very low number of taxa labelled with the ecological index $\mathrm{K}_{1}(1$ taxon $-0.52 \%)$ resulted from the negligible influence of the oceanic climate. The mean value of $\mathrm{K}-3.27$ confirmed that the plant cover of the permanent grassland on the solonetz and solonchakic solonetz soils in the vicinity of the town of Novi Kneževac was well adapted to the continental climate of the studied location. This type of climate is characterized by low winter and high summer temperatures and an adverse semidry period during the vegetation period (from mid-July to late September) characterized by a low rainfall, low air humidity and considerable fluctuations in daily temperature.

\section{Conclusions}

The plant cover of the grassland on the solonetz and solonchakic solonetz soils in the vicinity of the town of Novi Kneževac was found to comprise 205 taxa and 12 plant communities. The recorded taxa included 177 species, six subspecies, eight varieties, 13 forms and 1 lusus. The following plant communities were recorded: ass. Scirpo-Phragmitetum W. Koch 1926, ass. Bolboschoenetum maritimi continentale Soó (1927) 1957, ass. Acorelletum pannonici Soó (1939) 1947, ass. Puccinelletum limosae (Rapcs. 1927) Soó 1930, ass. Pholiuro-Plantaginetum tenuiflorae (Rapcs. 1927) Wendel. 1943, ass. Hordeetum histricis (Soó 1933) Wendel. 1943, ass. Camphorosmetum annuae (Rapcs. 1916) Soó 1933 corr. Soó 1938, ass. Agrostio-Alopecuretum pratensis Soó (1933) 1947, ass. AgrostioEleochariti-Alopecuretu geniculati (Magyar 1928) Soó (1939) 1947, ass. Artemisio-Festucetum pseudovinae (Magyar 1928) Soó 1945, ass. Achilleo-Festucetum pseudovinae (Magyar 1928) Soó 1945, and ass. Festuco-Andropogonetum ischaemi Vučk. 1985. The ecological analysis of plant cover included 191 taxa, i.e. 177 species, six subspecies, three varieties (because their higher taxonomic categories were not recorded in the analyzed flora) and five forms (because their higher taxonomic categories were not recorded in the analyzed flora) as well as all of the 12 recorded communities. The ecological analysis of the plant cover indicated that halophytes made $30.37 \%$ of the flora of the grassland on the solonetz and solonchakic solonetz soils surrounding the town of Novi Kneževac, and that the stands of the recorded plant communities grew on sites that differed considerably in the salt content of the rhizosphere soil layer. On average, these sites were moderately dry $(F-2.72)$ and moderately basic ( $R$ - 3.26), with moderate contents of nitrogen and nitrogen-containing substances $(\mathrm{N}$ - 3.07), a medium humus content ( $\mathrm{H}-2.94)$ and 
a moderately favourable aeration (D - 3.99). The meadow-type plant cover of the studied location was dominated by thermophilous plants adapted to full light ( $\mathrm{T}-4.05)$ as well as to some shading $(\mathrm{L}-3.84)$. The dominant plants were also adapted to the continental climate of the studied location ( $\mathrm{K}-3.27)$, which is characterized by low winter and high summer temperatures and an adverse semidry period during the vegetation period (from mid-July to late September) characterized by a low rainfall, low air humidity and considerable fluctuations in daily temperature. The above characteristics define the native grassland on the solonetz and solonchakic solonetz soils located in the vicinity of the town of Novi Kneževac as a poorly productive ecosystem.

\section{References}

Benka P, Salvai A (2005): Digitalizacija pedološke karte Vojvodine za potrebe geografskog informacionog sistema. Melioracije u održivoj poljoprivredi, Poljoprivreni fakultet, Departman za uređenje voda, Novi Sad, 53-59

Knežević A (1983): Prilog proučavanju halofitske vegetacije severnog Banata. Zbornik za prirodne nauke Matice srpske 65: 83-94

Knežević A (1994): Monografija flore vaskularnih biljaka na slatinama u regionu Banata (Jugoslavija). Matica srpska, Novi Sad
Knežević A, Boža P, Stojanović S, Milošev D, Nikolić Lj, Lazić D, Stojšić V (2003): Specifičnosti i ugroženost biljnog pokrivača zaslanjenih staništa priobalja akvatorije Rusande. Zaštita životne sredine gradova i prigradskih naselja. Ekološki pokret grada Novog Sada, Novi Sad, 289-294

Knežević A, Boža P, Milošev D, Lazić D (2005a): Specifičnost biljnog pokrivača priobalja akvatorije Slano Kopovo (Vojvodina, Srbija). Melioracije u održivoj poljoprivredi, Poljoprivredni fakultet Novi Sad, Departman za uređenje voda, Novi Sad, 76-81

Knežević A, Boža P, Stojanović S, Lazić D, Nikolić Lj (2005b): Flora of saline sites in the riparian zone of the Ostrovo aquatorium (Melenci - the Vojvodina province). Contemporary Agric. 54: 243-247

Knežević A, Džigurski D, Milošev D, Ljevnaić-Mašić B, Šeremešić S, Belić M (2009a): Ekološka analiza flore prirodnog pašnjaka na solonjecu u okolini naselja Kumane. Acta herbologica 18: 77-86

Knežević A, Boža P, Stankov M, Nikolić Lj, Stojanović S, Džigurski D, Ljevnaić B, Polić D (2009b): Plant cover of the saline grassland in the riparian zone of the Okanj oxbow lake (the Vojvodina province, Serbia). Annals of faculty of engineering Hunedoara - Journal of Engineering 7 (4): 189-194

Knežević A, Džigurski D, Ljevnaić-Mašić B, Cupina B, Milošev D (2011): Plant cover of natural pastures located in the vicinity of the town of Novi Kneževac. Contemporary Agric. 60: 22-30

Landolt E (1977): Ökologische Zeigerwerte zur Schweizer Flora, Veröffentlichungen des Geobotanischen Institutes der ETH, Stiftung Rübel, 64, Heft, Zürich

Ljevnaić-Mašić B (2010): Hidrofite Osnovne kanalske mreže Hidrosistema DTD na području Banata. Doktorska disertacija, Prirodno-matematički fakultet, Novi Sad

\title{
Ekološka analiza biljnog pokrivača prirodnog pašnjačkog ekosistema u okolini naselja Novi Kneževac
}

\author{
Aleksa Knežević • Branka Ljevnaić-Mašić • Dejana Džigurski · Branko Ćupina
}

Izvod: U biljnom pokrivaču pašnjaka, na solonjecu i solonjecu solončakastom, u okolini naselja Novi Kneževac (Vojvodina, Srbija) konstatovano je 205 taksona i sastojine 12 biljnih zajednica. Medu konstatovanim taksonima je: 177 vrsta, 6 podvrsta, 8 varijeteta, 13 formi i 1 luzus. Za ekološku analizu flore izdvojen je 191 takson. Među njima je 177 vrsta, 6 podvrsta, 3 varijeteta, tj. Aster tripolium L. var.pannonicus (Jacq.) Beck, Chenopodium rubrum L. subsp. botryoides Sm. var. crassifolium (Hornem) Kov. i Sonchus arvensis L. var. uliginosus (M.B.) Grec., jer njihove više taksonomske kategorije nisu zabeležene u istraživanoj flori i 5 formi tj. Aster sedifolius L. f. subsquamosus Soó, Bromus commutatus Schrad. f. violaceus Podp., Mentha aquatica L. f. erromera Top., Poa bulbosa L. f. vivipara Koel. i Scleranthus annus L. f. minimus Schur., jer njihove više taksonomske kategorije nisu zabeležene u istraživanoj flori. Za ekološku analizu vegetacije analizirane su satojine svih 12 zabeleženih zajednica tj. ass. Scirpo-Phragmitetum W. Koch 1926, ass. Bolboschoenetum maritimi continentale Soó (1927) 1957, ass. Acorelletum pannonici Soó (1939) 1947, ass. Puccinelletum limosae (Rapcs. 1927) Soó 1930, ass. Pholiuro-Plantaginetum tenuiflorae (Rapcs. 1927) Wendel. 1943, ass. Hordeetum histricis (Soó 1933) Wendel. 1943, ass. Camphorosmetum annuae (Rapcs. 1916) Soó 1933 corr. Soó 1938, ass. Agrostio-Alopecuretum pratensis Soó (1933) 1947, ass. Agrostio-Eleochariti-Alopecuretu geniculati (Magyar1928) Soó (1939) 1947, ass. Artemisio-Festucetum pseudovinae (Magyar 1928) Soó 1945, ass. Achilleo-Festucetum pseudovinae (Magyar 1928) Soó 1945 i ass. FestucoAndropogonetum ischaemi Vučk. 1985. Na osnovu ekološke analize biljnog pokrivača konstatovano je da u flori pašnjaka, na solonjecu i solonjecu solončakastom, u okolini naselja Novi Kneževac halofitama pripada 30,37 \% analiziranih taksona, te da su sastojine zabeleženih zajednica razvijene na staništima čiji je sadržaj soli u rizosfernim slojevima zemljišta vrlo različit. Prosečno to su: umereno suva (F - 2,72), umereno bazna (R - 3,26), umereno sadržajem azota i azotnih materijama obezbeđena staništa $(\mathrm{N}-3,07)$, sa srednjim sadržajem humusa $(\mathrm{H}-2,94)$ i umereno povoljnom aerisanošću $(\mathrm{D}-3,99)$. $U$ njihovom livadskom biljnom pokrivaču dominiraju termofilne biljke $(T-4,05)$ prilagođene punoj svetlosti, ali i izvesnoj zasenjenosti $(\mathrm{L}-3,84)$ i kontinentalnoj klimi istraživanog područja (K - 3,27).

Ključne reči: biljni pokrivač, ekološki indeksi, Novi Kneževac, prirodni pašnjak, solonjec, solonjec solončakasti, taksoni 